\title{
The Effectiveness of Classroom and Online Learning: A Study for Social Education Students during Covid-19
}

\author{
Rabeea Mohammed Mansour Imleesh ${ }^{1 *}$, Ibrahim Abdelrahim Ibrahim Humaida ${ }^{2}$, Meli Adriani \\ Hotma Hasibuan $^{3}$ \\ ${ }^{1}$ University of Alzawya, Libya; ${ }^{2}$ Omdurnan Islamic University, Sudan; ${ }^{3}$ Universitas Negeri Semarang, \\ Indonesia \\ *e-mail: rabeeaimleesh@gmail.com
}

\begin{abstract}
Most of the teaching in secondary schools and colleges is given on a classical basis. That is, the teacher gives an explanation to a number of students orally. Many think, this form of classical teaching is the most appropriate form. Basically, with the classical form of teaching a teacher can teach a group with an unlimited number of students. Some students benefit from the online courses that provide opportunities for students. Students in schools that don't offer statistics classes may be able to learn statistics with virtual lessons. If students fail and are late on assignments during the day, they may be able to catch up at night. So, almost certainly, online classes sometimes benefit students. The results of the Mann Whitney test and the gain score indicate that classroom learning is more effective than online learning with the following values: $(Z=-2.209, p=0.028<0.05)$. From the series of analyzes above, it can be concluded that of the two types of experiments tested, both classroom learning and online learning are effective. Furthermore, to see which learning technique is more effective between classroom learning and online learning, it is tested again and it turns out that the test results show that classroom learning techniques are more effective than online learning techniques for social education students.
\end{abstract}

Keywords:

Classroom Learning; Online Learning; Covid-19; Social Education Students. 


\begin{abstract}
ABSTRAK
Sebagian besar pengajaran di sekolah menengah dan perguruan tinggi diberikan secara klasikal. Artinya, guru memberikan penjelasan kepada sejumlah siswa secara lisan. Banyak yang beranggapan, bentuk pengajaran klasik ini adalah bentuk yang paling tepat. Pada dasarnya dengan bentuk pengajaran klasik seorang guru dapat mengajar kelompok dengan jumlah siswa yang tidak terbatas. Beberapa siswa mendapat manfaat dari kursus online yang memberikan peluang bagi siswa. Siswa di sekolah yang tidak menawarkan kelas statistik mungkin dapat mempelajari statistik dengan pelajaran virtual. Jika siswa gagal dan terlambat mengerjakan tugas di siang hari, mereka mungkin dapat mengejar ketinggalan di malam hari. Jadi, hampir pasti, kelas online terkadang bermanfaat bagi siswa. Hasil uji Mann Whitney dan gain score menunjukkan bahwa pembelajaran di kelas lebih efektif daripada pembelajaran online dengan nilai sebagai berikut: $(Z=-$ $2.209, p=0.028<0.05$ ). Dari rangkaian analisis di atas, dapat disimpulkan bahwa dari dua jenis eksperimen yang diujikan, pembelajaran di kelas dan pembelajaran online efektif. Selanjutnya untuk melihat teknik pembelajaran mana yang lebih efektif antara pembelajaran di kelas dan pembelajaran online diujicobakan kembali dan ternyata hasil tes menunjukkan bahwa teknik pembelajaran di kelas lebih efektif daripada teknik pembelajaran online bagi siswa pendidikan sosial.
\end{abstract}

Kata Kunci:

Pembelajaran di Kelas; Pembelajara On-line; Covid-19; Siswa Pendidikan Sosial

\title{
1. Introduction
}

Information technology is currently developing very rapidly, one of which is in the field of education. Previously, we had to study face to face, now we can use e-learning as a learning medium. With e-learning, we can include learning materials in the form of writing, voice, video and much more. We can also make quizzes or exams using e-learning, and the implementation is also carried out online. ELearning makes learning can be done from anywhere and anytime. The same thing was also expressed by Lantip and Rianto (2011) that information technology is defined as knowledge in the field of computer-based information and its development is very rapid.

The modern era is identified with the era of digital society. Every human activity will be driven through a series of digital technologies. This technology is operated by pressing several digits (numbers) which are arranged in various sequences. The relationship that is built between individuals is a digital exchange relationship, each human being only carries out a series of transactions or interactions through digital symbols. Information is a record of observed phenomena, or it can be in the form of decisions made. Online learning is a form of distance learning or distance education, which has long been a part of the American education system, and it has become the largest sector of distance learning in recent years (Bartley \& Golek, 2004; Evans \& Haase, 2001).

According to Achadiyah (2014). One of the advantages of e-learning can be used as an online exam media. Research related to e-learning evaluation was conducted by Agus by asking students 
about criticisms and suggestions for implementing e-learning based learning Sutedjo (2013). In addition, there is also Hanum who conducts e-learning evaluations using the discrepancy model or other terms program gap evaluation. Hanum uses a quantitative approach in which measures program expectations and compares them with the implementation of the Hanum program (2013). The instructor taught the same content to students enrolled in both sections of the course. The students using WebCT met with the instructor three times during the semester. These meetings included an introduction to WebCT features and use, time for assessments, student presentations, the final exam, and instructor evaluation.

The offline or classroom sections receive content through lectures, activities, and cooperative exercises in class. They also have the same readings, projects, quizzes, and exams as the online section. But in this online section students receive content through online modules, discussion forums, interactive chat sessions with instructors and classmates, links to video clips featuring class content, and links to relevant Web pages such as zoom, google classroom, or group class in whats'app. In one of the first experimental studies on the effects of traditional teaching versus online learning in which students were randomly assigned to live lectures versus watching the same lecture online while additional material and instructions were the same, Figlio et al. (2010) found simple evidence that traditional formats have a positive effect compared to online formats.

The impact of the learning environment in developing learning outcomes is explored by educational researchers. There are studies that have found that it empirically identifies the relationship between learning and the academic environment. Haertela, Walberg, and Haertela (2008) found between students' perceptions of the social psychological environment of the classroom and their learning outcomes. Web-based technology significantly changes the teaching and learning environment. Proponents of online learning have seen that it can be effective in removing barriers while providing increased convenience, material exchange, unbeatable learning, and traditional faceto-face feedback.

A study by Phipps and Merisotis (1999) found that several major deficiencies were inherent in research on the effectiveness of online learning, including no control for extraneous variables, lack of randomization for sample selection, weak validity and reliability of measurement tools, and no control for "reactive effect". Based on the description above, it needs to be researched about the effectiveness of classroom and online learning: a study for social education students during covid-19. In 2020 was a tough year for the world when suddenly the Covid-19 outbreak appeared, which initially appeared locally in Wuhan-China, then spread and devastated the joints of the world economy. Global data as of 2 June 2020 shows that there are 6,140,934 people from 216 countries in the world who have been confirmed as the Covid-19 outbreak and 373,548 of them have died.

When Covid-19 began to emerge at the end of 2019 and began to spread and explode locally in China at the end of January 2020, then spread throughout the world throughout February to the end of July, not a single institution (both from government, private sector, universities, as well as the 
World Bank and The IMF) took it into account, so that the economic outlook for 2020 and the years thereafter is still predicted with normal assumptions.

The United Nations Conference on Trade and Development (UNCTAD, 2020) stated that Covid-19 hit developing countries at a time when they were struggling with an unsustainable debt burden for years. By the end of 2018 the total debt stock of developing countries reached 191 percent (or nearly double). When Covid-19 began to spread in Indonesia, the President of the Republic of Indonesia Joko Widodo issued a Regulation in Lieu of Law (Perpu) Number 1 of 2020 concerning State Financial Policy and Financial System Stability for Handling the Corona Virus Pandemic. The learning system is basically ways to achieve learning objectives, namely the achievement of maximum learning outcomes by students in learning activities. Learning outcomes are an important factor in the teaching and learning process.

The learning atmosphere is face to face and learning is directed so that students can develop their potential, this means that in the educational process students are educational subjects (educational actors) not as learning objects. In the learning process, students are not seen as passive individuals who are only recipients of information, but are seen as active individuals who have the potential to develop. According to Trianto (2011) in the book The Integrated Learning Model in which there are objectives, activity stages, learning environment and classroom management. The form of the classroom learning system has several forms of models, namely individual learning models, classical learning models, and thematic learning models. Most of the teaching in secondary schools and colleges is given on a classical basis. That is, the teacher gives an explanation to a number of students orally. Many think, this form of classical teaching is the most appropriate form. Basically, with the classical form of teaching a teacher can teach a group with an unlimited number of students. During classical teaching, students have to do two things, namely listening and taking notes. And the schedule of courses or subjects is not determined in advance by conferring with the teacher concerned.

According to Nahar et.al (2017) Classical education focuses on the ways, methods and tools to simplify a given text book, which is highly depends on the instructor skills. Moreover, in classical students usually gather information through the instructions that are given by fully trained instructors. In the context of credibility, security is a major concern on on-line education (Heafner et al. 2015). Educators may not be able to authenticate that the actual student who was supposed to cover the material, perform the exam, etc. is the one who actually performed it. In addition to the technological requirements related to security protection of information equipment and premises.

Online learning is a form of distance learning or distance education, which has long been part of the American education system, and has become the largest distance learning sector in recent years (Bartley \& Golek, 2004; Evans \& Haase, 2001). What attracts the most attention to online learning is the high school education environment. The increasing cost of education in this section and the importance of a diploma in high school are well documented. The lifetime income gap between high school and college graduates continues to widen and compete (Dynarski \& Scott-Clayton, 2013). 
There is hope that online learning can provide classroom education to anyone, anywhere, and anytime as long as they have internet access. There are some of the most prominent websites and companies built on this premise, and many respected and valued scholars and entrepreneurs have high hopes and expectations for online learning, especially for massive open online courses (Bowen, 2013; Fisher, 2012; Koller \& Ng, 2012; Lewin, 2012; Selingo, 2013). Some students benefit from the online courses that provide opportunities for students. Students in schools that don't offer statistics classes may be able to learn statistics with virtual lessons. If students fail and are late on assignments during the day, they may be able to catch up at night. So, almost certainly, online classes sometimes benefit students. Student performance is a multidimensional concept; successful completion of a course, course withdrawals, grades, added knowledge, and skill building are among some of the aspects. Nevertheless, researchers have been interested in differences in performance between the two modes of instruction.

It is important to note that, despite the proliferation of literature on online learning, there is a relative scarcity of true, original research dedicated to the effectiveness of classroom and online learning: a study for social education students during covid-19.

\section{Method}

The related fieldwork data to this research were collected by using a structured questionnaire survey which was considered the most widely used data collection technique for conducting surveys since most of the literature mentioned studies. Using postal questionnaire is mostly suited to surveys whose purpose and objectives are clear enough to be explained in a few paragraphs which are carefully chosen and guaranteed in this research. Moreover it offers relatively high validity of results and a quick method of conducting the survey. Therefore the researcher adopted this strategy.

The questionnaire design is divided into 4 parts. The first part is identity, which is asking about name, gender, department / faculty. The second part is to ask the preferred learning method between e-learning and conventional (face to face). The third part is the assessment of learning methods according to the criteria. The next stage is sampling. The sampling technique used is random sampling in which the sample is taken according to the proportions specifically needed for students majoring in social science education. The population in this study was 16 students of social education using a survey.

\section{Result and Discussion}

The collected data (pretest-posttest) was prepared before being analyzed. Comparisons between student classroom learning and online learning are all at a high level. Based on the results of the analysis, it shows that classroom learning is effective more than online learning. 
Table1. Mean, SD, and result of test wilcoxon

\begin{tabular}{|c|c|c|c|c|c|c|}
\hline \multirow{2}{*}{$\begin{array}{c}\text { Techniq } \\
\text { ue }\end{array}$} & \multicolumn{2}{|c|}{ Pretest } & \multicolumn{2}{|c|}{ Posttest } & \multirow{2}{*}{$Z^{*}$} & \multirow{2}{*}{$\mathrm{P}$} \\
\hline & M & SD & M & SD & & \\
\hline online & $\begin{array}{l}71,5 \\
0\end{array}$ & 5,97 & 59,12 & 7,72 & $2, \overline{-}$ & $0,012<0,05$ \\
\hline $\begin{array}{l}\text { Class } \\
\text { room }\end{array}$ & $\begin{array}{c}77,0 \\
0\end{array}$ & 7,01 & 58,00 & 6,48 & 2,52 & $0,012<0,05$ \\
\hline
\end{tabular}

The results of statistical tests using the Wilcoxon test in this study indicate that classroom learning and online learning are effective in the teaching and learning process. The results of statistical tests shown by each technique are as follows: online learning $(Z=-2.52, p=0.012<0.05)$. Meanwhile, classroom learning shows $(Z=-2.52, p=0.012<0.05)$.

Table 2. mean, SD, and result of test Mann withney

\begin{tabular}{lcccc}
\hline \multirow{2}{*}{ Technique } & \multicolumn{2}{c}{ Gain } & \multirow{2}{*}{$\mathbf{Z}^{* *}$} & $\mathbf{P}$ \\
\cline { 2 - 3 } $\begin{array}{l}\text { Online } \\
\text { classroom }\end{array}$ & $\mathbf{M}$ & $\mathbf{S D}$ & & \\
& $-15,69$ & 6,47 & $-2,21$ & $0,028<0,05$ \\
& & & & \\
\hline
\end{tabular}

The results of the Mann Whitney test and the gain score indicate that classroom learning is more effective than online learning with the following values: $(Z=-2.209, p=0.028<0.05)$. From the series of analyzes above, it can be concluded that of the two types of experiments tested, both classroom learning and online learning are effective. Furthermore, to see which learning technique is more effective between classroom learning and online learning, it is tested again and it turns out that the test results show that classroom learning techniques are more effective than online learning techniques for social education students.

It's no surprise that face-to-face courses are more effective on average. Being in person with teachers and other students creates social pressure and benefits that can help motivate students to engage. Some students perform well in online courses such as face-to-face courses, some may actually perform better, but, on average, students perform worse in online settings, and this is especially true for students with weaker academic backgrounds.

Students who struggle in face-to-face classes tend to struggle even more online. While research on virtual schools in education did not address these differences directly, the student research I 
worked with found very little difference in learning for high achieving students in both online and inperson environments. On the other hand, underachieving students performed worse in online courses than face-to-face courses.

The conventional method (face-to-face) is still considered better by students than online learning because it is easier to understand the material and it is easier to interact with teachers. But online-learning itself also has advantages when compared to conventional, namely in terms of flexibility in lecture time and ease of submitting assignments. According to Nahar et.al (2017) Classical education focuses on the ways, methods and tools to simplify a given text book, which is highly depends on the instructor skills. Moreover, in classical students usually gather information through the instructions that are given by fully trained instructors.

There is hope that online learning can provide classroom education to anyone, anywhere, and anytime as long as they have internet access. There are some of the most prominent websites and companies built on this premise, and many respected and valued scholars and entrepreneurs have high hopes and expectations for online learning, especially for massive open online courses (Bowen, 2013; Fisher, 2012; Koller \& Ng, 2012; Lewin, 2012; Selingo, 2013).

\section{Conlusions}

The research findings suggest that students in the online-based portion of the course learn less but not significantly more than students in the class-based portion of the course. online is a growing medium, a medium that is destined to become faster and more interactive. Future advances in online technology will make it increasingly possible to provide learning experiences that are somewhat comparable to classroom-based learning experiences that students today cannot. There is certainly a need for ongoing research to continue to test the effectiveness of online-based developments course delivery technology.

\section{References}

Bowen, W. G. 2013. Higher education in the digital age. Princeton University Press.

Fisher, D. 2012. Warming Up to MOOC's. The Chronicle of Higher Education Blogs: ProfHacker

Heafner, T.L., Hartshorne, R. \& Petty, T. eds., 2015. Exploring the Effectiveness of Online Education in $\mathrm{K} 12$ Environments, IGI Global. Available at: http://services.igiglobal.com/resolvedoi/resolve.aspx?doi=10.4018/978-1-4666-6383-1. acces on 27 agust 2020

Lewin, T. 2012. Anant Agarwal Discusses Free Online Courses Offered by a Harvard/M.I.T. Partnership. The New York Times. Retrieved from http://www.nytimes.com/2012/07/20/education/edlife/anant-agarwal-discusses-freeonlinecourses-offered-by-a-harvard-mit-partnership.html acces on 28 august 2020 
Nahar, M.O., Mohammed Abu Shquier., Izzat Alsmadi., and Iyad Alazzam. 2017. Students Performance between Classical and Online Education: A Comparative Study. Article in International Journal of Continuing Engineering Education and Life-Long Learning .

Trianto. 2011. Model Pembelajaran Terpadu. Jakarta: Bumi Aksara.

World Bank. 2020. "East Asia and Pacific in the Time of COVID-19"East Asia and Pacific Economic Update (April), World Bank, Washington, DC. Doi: 10.1596/978-1-4648-1565-2. License: Creative Commons Attribution CC BY 3.0 IGO

World Health Organization (WHO). (2020). Public health criteria to adjust public health and social measures in the context of COVID-19, https://www.who.int/publications-detail/publichealth-criteria-to-adjust-public-health-and-social-measures-in-the-context-of-Covid-19. acces on 30 july 2020.

United Nations Conference on Trade and Development (UNCTAD). (2020). From the Great Lockdown to the Great Meltdown: Developing Country Debt in the Time of Covid-19, https://unctad.org/en/PublicationsLibrary/gdsinf2020d3_en.pdf.acces on 30 july 2020. 